\title{
Design and Analysis of Grid Connected Transformerless Solar Inverter
}

\author{
Rajesh \\ Assistant Professor, Department of Electrical and Electronics Engineering, PNSIT, Bengaluru
}

\begin{abstract}
The design of Transformerless converter concept is developed extensively for the increasing of the efficiency and reliability of the electrical systems which in-turn reduces the major power losses. Consider the conventional inverter where the power from the DC source is initially inverter and then the inverted voltage is boosted using low frequency power transformer. The use of the low frequency transformer increases the cost and size of the system which also increases considerable amount of power loss hence, the necessity of development of a low cost lossless power technology has generated. In photovoltaic applications, transformerless power converter technology is in trend where in, the system is developed such that the output of the solar panel is connected to a single power electronic module which generates the desired output. The modified boost converter uses a couple of inductors at the input side to produce ripple free current without utilization of LC filters. The performance of the modified boost converter has been increased positively with high power conversion capability. The Transformerless grid synchronized photovoltaic system with conventional voltage source inverter may cause electrical safety issue of ground leakage current which is generated using the presence of parasitic capacitance photovoltaic modules and is eliminated using the implementation of bipolar SPWM technology for voltage source inverter. The proposed system is designed and simulated using PSIM.
\end{abstract}

Keywords: Transformer less inverter, step-up DC-DC converter, low ground-leakage current, power converter efficiency.

\section{INTRODUCTION}

Solar energy systems which are based on photovoltaic (PV) modules have influenced a lot of interest in this decade due to their impact of clean and limitless production of electrical energy. With the increase in power demand and the limitations of conventional energy sources plays important role to overcome the drawbacks of conventional sources of electrical energy. Solar energy systems are well developed as they are not prone to low life span and PV module malfunction. The main applications of the solar energy systems are found in household and grid connected systems, especially standalone systems. These systems are gaining more popularity as they are reducing installation costs with improved safety and maximizing the solar energy harvest capacity and has become emerging application and a remarkable market share in future.

PV system supplies the generated solar electricity to the load through an inverter and to the power grid if the system has more power generating capacity for providing more energy than the load demand. Since the greenhouse effect is considered to be the most severe problem this system is proved to be one of the greatest eco-friendly technological improvement. In India there is huge gap between the load demand and the energy availability. The major challenges which are faced by India in energy supply are:

- Energy produced is way more less than the actual demand hence there is an energy crisis in a major part of India.
- $\mathrm{CO} 2$ emission in India has increased to an undesirable limit which is due to the use of conventional energy sources.

The above challenges can be tackled by using nonconventional energy sources like solar energy and wind energy. In grid connected systems, the output of the solar panel is connected to a capacitor bank for energy storage and connected to a boost converter to adjust the voltage ratio and for voltage scaling purpose. The power after the voltage scaling is connected to the single phase inverter system which converts the DC power to AC power without the utilization of the transformer for scaling purpose. The use of conventional boost converter instead of a transformer at the DC side is advantageous in majority conditions but also have few limitations. The limitations of conventional boost converter are as listed below:

- High input ripple current since the inductor is in series with the source.

- Inherent EMI issues.

Hence a modified boost converter is developed to eliminate the limitations of conventional boost converter and increase the reliability and feasibility of Transformerless photovoltaic applications.

The proposed modified boost converter possess zero ripple current at the input side. The PV system has high ground leakage current produced due to the parasitic capacitance of the solar panel. Hence it is necessary to increase the 
Vol. 5, Issue 1, January 2017

safety of the solar PV system by providing galvanic isolation which can be achieved by using high or low frequency transformers. The use of transformers makes the application very bulky and lossy resulting the system to be cost ineffective. Thus transformer less power converter is preferred for PV system applications. Another aspect of PV application is to ensure that the solar inverter application module is working at the Maximum Power Point (MPP). The main specification of the transformer less solar inverter is that current is to be drawn from the photovoltaic modules and evacuated to the utility load.

The advantages of transformer less solar inverters are:

- Highly reliability due to the implementation modifies boost converter.

- Higher efficiency due to the elimination of high or low frequency transformers.

- Low Manufacturing and installation costs.

\section{CONFIGURATION OF THE PROPOSED SYSTEM}

In the proposed system, the energy from the solar panel is evacuated using a modified boost converter which will boost the input voltage to grid specification voltage. The output of the modified boost converter is directly fed to the voltage source inverter which is controlled using a PWM technique. The modified boost converter is controlled using MPPT technique which is helpful to evacuate maximum power available from the solar panel.

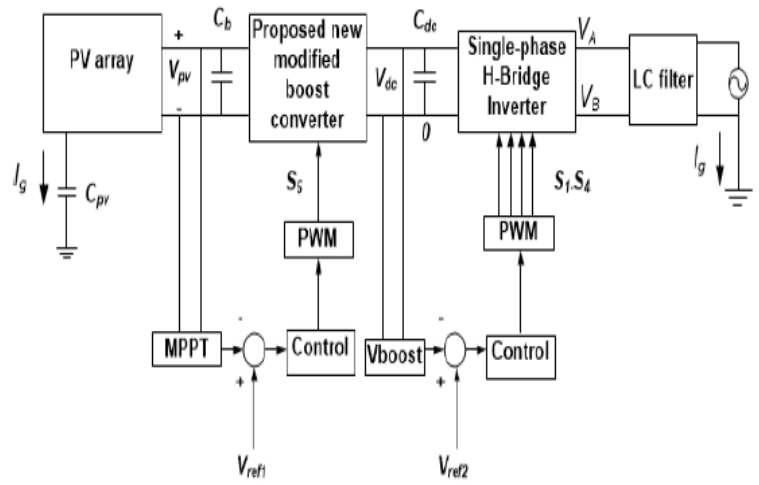

Fig 1. Block diagram of Transformerless grid connected solar inverter.

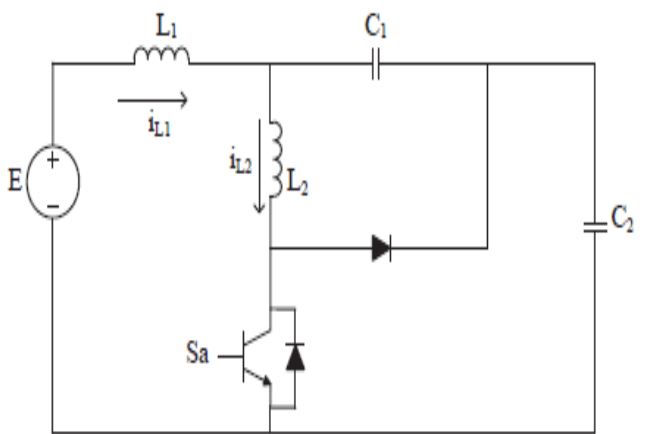

Fig 2. Circuit diagram of modified boost converter
The single phase $\mathrm{H}$-bridge inverter generates the AC power which is compatible with the single phase grid specifications using a precise LC circuit design. The circuit diagram of the proposed modified boost converter is as shown.

\section{A. ANALYSIS OF PROPOSED MODIFIED BOOST} CONVERTER

For a PV system, the boost converter is highly prefererable because the inductor is in series with source so that input is always continuous which is not in case of buck or buck -boost converter (because the switch is in series with source, during turn-off mode input will be disconnected f and energy will not be utilized). Hence boost converter is more suitable for PV applications comparatively Since boost converter is having high ripple current and pulsating current which leads to power loss from a non linear source (like PV panel).

In this method, a new modified boost converter is operates in continuous current mode with zero ripple current in series inductance. The proposed modified boost converter is as shown in Fig 3. It consists of inductors (L1 and L2) Capacitor $(\mathrm{C} 1 \& \mathrm{C} 2)$ diode $\mathrm{D}$, Electronic switch $(\mathrm{S})$.

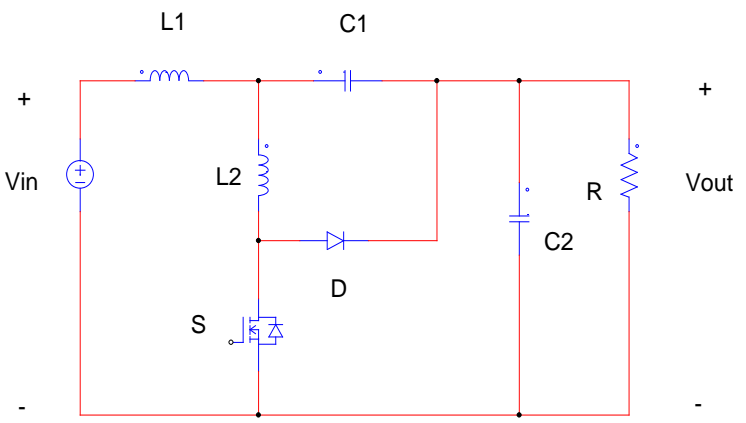

Fig 3. Circuit configuration of modified boost converter

The proposed converter operates in two modes. The modes of operation indicated the parameter status of the circuit topology at every switching of each switches. The analysis can be carried out with the following parameters:

$\mathrm{V}_{\text {in }}$ - Input voltage.

$\mathrm{V}_{\text {out }}-$ Output voltage.

$\mathrm{V}_{\mathrm{L} 1}, \mathrm{~V}_{\mathrm{L} 2}-$ Voltage across the inductors $\mathrm{L}_{1}$ and $\mathrm{L}_{2}$ respectively.

$\mathrm{V}_{\mathrm{c} 1}, \mathrm{~V}_{\mathrm{c} 2}-$ Voltage across the capacitors $\mathrm{C}_{1}$ and $\mathrm{C}_{2}$ respectively.

$\Delta \mathrm{i}_{\mathrm{L} 1}, \Delta \mathrm{i}_{\mathrm{L} 2}-$ Change in the inductor currents $\mathrm{L}_{1}$ and $\mathrm{L}_{2}$ repectively.

Mode 1: (Switch $\mathrm{S}$ is closed and diode $\mathrm{D}$ is reverse biased) In this mode the switch $\mathrm{S}$ is closed and diode $\mathrm{D}$ is reverse biased. The equivalent circuit is as shown in Fig 4 .

The analysis of this mode is as follows:

Apply KVL to the loop $\mathrm{V}_{\text {in }}, \mathrm{L}_{1}$, and $\mathrm{L}_{2}$.

$\mathrm{V}_{\mathrm{in}}-\mathrm{V}_{\mathrm{L} 1}-\mathrm{V}_{\mathrm{L} 2}=0$

Rearranging the above equation,

$\mathrm{V}_{\mathrm{in}}=\mathrm{v}_{\mathrm{L} 1}+\mathrm{v}_{\mathrm{L} 2}$ 
Vol. 5, Issue 1, January 2017

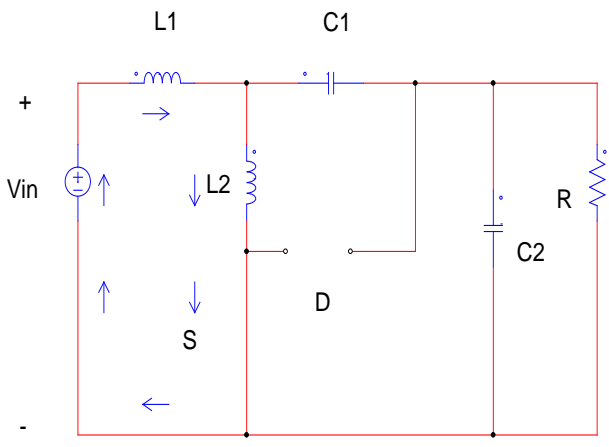

Fig 4 Equivalent circuit when switch $\mathrm{S}$ is closed

Since the voltage across the inductor is given by $\mathrm{v}_{\mathrm{L}}=\mathrm{L}$ * $\left(\frac{\mathrm{di}_{\mathrm{L}}}{\mathrm{dt}}\right)$

Then the equation (2) becomes,

$\mathrm{V}_{\text {in }}=\mathrm{L}_{1} *\left(\frac{\mathrm{di}_{\mathrm{L} 1}}{\mathrm{dt}}\right)+\mathrm{L}_{2} *\left(\frac{\mathrm{di}_{\mathrm{L} 2}}{\mathrm{dt}}\right)$

The above equation can be written as:

$\mathrm{V}_{\text {in }}=\mathrm{L}_{1} *\left(\frac{\Delta \mathrm{i}_{\mathrm{L} 1}}{\mathrm{DT}_{\mathrm{s}}}\right)+\mathrm{L}_{2} *\left(\frac{\Delta \mathrm{i}_{\mathrm{L} 2}}{\mathrm{DT}_{\mathrm{s}}}\right)$

$\mathrm{DT}_{\mathrm{S}}=\left[\frac{\mathrm{L}_{1} * \Delta \mathrm{i}_{\mathrm{L} 1}+\mathrm{L}_{2} * \Delta \mathrm{i}_{\mathrm{L} 2}}{\mathrm{~V}_{\mathrm{in}}}\right]$

Since $t_{\text {on }}=D_{\mathrm{s}}$

Therfore,

$\mathrm{t}_{\mathrm{on}}=\left[\frac{\mathrm{L}_{1} * \Delta \mathrm{i}_{\mathrm{L} 1}+\mathrm{L}_{2} * \Delta \mathrm{i}_{\mathrm{L} 2}}{\mathrm{~V}_{\mathrm{in}}}\right]$

Mode 2: (Switch $\mathrm{S}$ is opened and diode $\mathrm{D}$ is forward biased)

In this mode the switch $\mathrm{S}$ is opened and diode will be forward biased to provide path for the inductor current. The equivalent circuit is as shown in Fig 2.10.

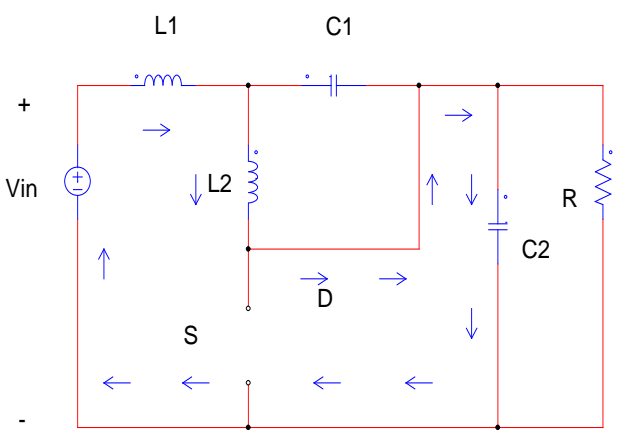

Fig 5 Equivalent circuit when switch $\mathrm{S}$ is opened

The analysis of this mode is as follows:

Apply KVL to the loop which contains $\mathrm{V}_{\mathrm{in}}, \mathrm{L}_{1}, \mathrm{~L}_{2}$, and $\mathrm{C}_{2}$. $\mathrm{V}_{\text {in }}-\mathrm{V}_{\mathrm{L} 1}-\mathrm{V}_{\mathrm{L} 2}-\mathrm{V}_{\mathrm{o}}=0$

The above equation can be written as:

$\mathrm{V}_{\text {in }}-\mathrm{V}_{\mathrm{o}}=\mathrm{v}_{\mathrm{L} 1}+\mathrm{v}_{\mathrm{L} 2}$

Since the voltage across the inductor is given by $\mathrm{v}_{\mathrm{L}}=\mathrm{L} *$ $\left(\frac{d_{L}}{d t}\right)$
Substituting in the equation (8),

$\mathrm{V}_{\text {in }}-\mathrm{V}_{\mathrm{o}}=\mathrm{L}_{1} *\left(\frac{\mathrm{di} \mathrm{i}_{\mathrm{L} 1}}{\mathrm{dt}}\right)+\mathrm{L}_{2} *\left(\frac{\mathrm{di}_{\mathrm{L} 2}}{\mathrm{dt}}\right)$

The above equation can be written as:

$\mathrm{V}_{\text {in }}-\mathrm{V}_{\mathrm{o}}=\mathrm{L}_{1} *\left(\frac{\Delta \mathrm{i}_{\mathrm{L} 1}}{(1-\mathrm{D}) \mathrm{T}_{\mathrm{s}}}\right)+\mathrm{L}_{2} *\left(\frac{\Delta \mathrm{i}_{\mathrm{L} 2}}{(1-\mathrm{D}) \mathrm{T}_{\mathrm{s}}}\right)$

$(1-\mathrm{D}) \mathrm{T}_{\mathrm{S}}=\left[\frac{\mathrm{L}_{1} * \Delta \mathrm{i}_{\mathrm{L} 1}+\mathrm{L}_{2} * \Delta \mathrm{i}_{\mathrm{L} 2}}{\mathrm{~V}_{\mathrm{in}}-\mathrm{V}_{\mathrm{o}}}\right]$

Since $\mathrm{t}_{\mathrm{off}}=(1-\mathrm{D}) \mathrm{T}_{\mathrm{s}}$

Therfore,

$\mathrm{t}_{\mathrm{off}}=\left[\frac{\mathrm{L}_{1} * \Delta \mathrm{i}_{\mathrm{L} 1}+\mathrm{L}_{2} * \Delta \mathrm{i}_{\mathrm{L} 2}}{\mathrm{~V}_{\mathrm{in}}-\mathrm{V}_{\mathrm{o}}}\right]$

In the modified boost converter the output voltage is always greater than the input voltage. Therfore $\left(\mathrm{V}_{\mathrm{in}}-\mathrm{V}_{\mathrm{o}}\right)$ is negative then $t_{\text {off }}$ becomes negative. Hence it is necessary to modify the equation (11) and (12) because $t_{\text {off }}$ cannot be negative.

$(1-\mathrm{D}) \mathrm{T}_{\mathrm{S}}=\left[\frac{\mathrm{L}_{1} * \Delta \mathrm{i}_{\mathrm{L} 1}+\mathrm{L}_{2} * \Delta \mathrm{i}_{\mathrm{L} 2}}{\mathrm{~V}_{\mathrm{o}}-\mathrm{V}_{\mathrm{in}}}\right]$

$\mathrm{t}_{\mathrm{off}}=\left[\frac{\mathrm{L}_{1} * \Delta \mathrm{i}_{\mathrm{L} 1}+\mathrm{L}_{2} * \Delta \mathrm{i}_{\mathrm{L} 2}}{\mathrm{~V}_{\mathrm{o}}-\mathrm{V}_{\mathrm{in}}}\right]$

Equation (7) can be written as:

$\left(\mathrm{V}_{\text {in }} * \mathrm{DT}_{\mathrm{s}}\right)=\mathrm{L}_{1} * \Delta \mathrm{i}_{\mathrm{L} 1}+\mathrm{L}_{2} * \Delta \mathrm{i}_{\mathrm{L} 2}$

Equation (11) can be written as:

$\left(\mathrm{V}_{\mathrm{o}}-\mathrm{V}_{\mathrm{in}}\right)(1-\mathrm{D}) \mathrm{T}_{\mathrm{s}}=\mathrm{L}_{1} * \Delta \mathrm{i}_{\mathrm{L} 1}+\mathrm{L}_{2} * \Delta \mathrm{i}_{\mathrm{L} 2}$

Substituting equation (15) in equation (16),

$\left(\mathrm{V}_{\mathrm{o}}-\mathrm{V}_{\mathrm{in}}\right)(1-\mathrm{D}) \mathrm{T}_{\mathrm{s}}=\left(\mathrm{V}_{\text {in }} * \mathrm{DT}_{\mathrm{s}}\right)$

Solving the above equation,

$\mathrm{V}_{\mathrm{o}}-\left(\mathrm{V}_{\mathrm{o}} * \mathrm{D}\right)-\mathrm{V}_{\text {in }}+\left(\mathrm{V}_{\text {in }} * \mathrm{D}\right)=\left(\mathrm{V}_{\text {in }} * \mathrm{D}\right)$

$\mathrm{V}_{\text {in }}=\mathrm{V}_{\mathrm{o}}(1-\mathrm{D})$

The output voltage is given by:

$\mathrm{V}_{\mathrm{o}}=\left[\frac{\mathrm{V}_{\text {in }}}{1-\mathrm{D}}\right]$

During $\mathrm{t}_{\mathrm{on}}$ interval,

Apply KVL to the second loop for Fig 2.2. The loop which contains $\mathrm{L}_{2}, \mathrm{C}_{1}$, and $\mathrm{C}_{2}$.

$\mathrm{V}_{\mathrm{c} 1}+\mathrm{V}_{\mathrm{c} 2}=\mathrm{v}_{\mathrm{L} 2}$

Substituting inductor equation to above equation,

$\mathrm{V}_{\mathrm{c} 1}+\mathrm{V}_{\mathrm{c} 2}=\mathrm{L}_{2} *\left(\frac{\mathrm{di}_{\mathrm{L} 2}}{\mathrm{dt}}\right)=\mathrm{L}_{2} *\left(\frac{\Delta \mathrm{i}_{\mathrm{L} 2}}{\mathrm{DT}_{\mathrm{s}}}\right)$

The above equation can be written as:

$\mathrm{t}_{\mathrm{on}}=\mathrm{DT}_{\mathrm{s}}=\left[\frac{\mathrm{L}_{2} * \Delta \mathrm{i}_{\mathrm{L} 2}}{\mathrm{DT}_{\mathrm{s}}}\right]$

During $\mathrm{t}_{\text {off }}$ period

Apply KVL to the second loop which contains $\mathrm{L}_{2}$ and $\mathrm{C}_{1}$.

$\mathrm{v}_{\mathrm{L} 2}=\mathrm{V}_{\mathrm{c} 1}$ 
Substituting inductor equation to above equation,

$\mathrm{v}_{\mathrm{L} 2}=\mathrm{V}_{\mathrm{c} 1}=\mathrm{L}_{2} *\left(\frac{\mathrm{di}_{\mathrm{L} 2}}{\mathrm{dt}}\right)=\mathrm{L}_{2} *\left(\frac{\Delta \mathrm{i}_{\mathrm{L} 2}}{(1-\mathrm{D}) \mathrm{T}_{\mathrm{s}}}\right)$

The above equation can be written as:

$\mathrm{t}_{\mathrm{off}}=(1-\mathrm{D}) \mathrm{T}_{\mathrm{s}}=\left[\frac{\mathrm{L}_{2} * \Delta \mathrm{i}_{\mathrm{L} 2}}{\mathrm{~V}_{\mathrm{c} 1}}\right]$

Since inductor current decreases linearly during $\mathrm{t}_{\mathrm{off}}$ interval then the above equation can be written as:

$\mathrm{t}_{\mathrm{off}}=(1-\mathrm{D}) \mathrm{T}_{\mathrm{s}}=-\left[\frac{\mathrm{L}_{2} * \Delta \mathrm{i}_{\mathrm{L} 2}}{\mathrm{v}_{\mathrm{c} 1}}\right]$

Equation (21) can be written as:

$\left(\mathrm{L}_{2} * \Delta \mathrm{i}_{\mathrm{L} 2}\right)=\left(\mathrm{V}_{\mathrm{c} 1}+\mathrm{V}_{\mathrm{c} 2}\right) \mathrm{DT}_{\mathrm{s}}$

Subsituting equation (28) in equation (27) then,

$(1-\mathrm{D}) \mathrm{T}_{\mathrm{s}}=-\left[\frac{\left(\mathrm{V}_{\mathrm{c} 1}+\mathrm{V}_{\mathrm{c} 2}\right) \mathrm{DT}_{\mathrm{s}}}{\mathrm{V}_{\mathrm{c} 1}}\right]$

Solving the above equation,

$\mathrm{V}_{\mathrm{c} 1}(1-\mathrm{D})=-\mathrm{V}_{\mathrm{c} 1} \mathrm{D}-\mathrm{V}_{\mathrm{c} 2} \mathrm{D}$

$V_{c 1}-V_{c 1} D=-V_{c 1} D-V_{c 2} D$

$\mathrm{V}_{\mathrm{c} 1}=-\mathrm{V}_{\mathrm{c} 2} \mathrm{D}$

The voltage across the capacitor $\mathrm{C}_{2}$ is same as the output voltage which is given by:

$\mathrm{V}_{\mathrm{o}}=\left[\frac{\mathrm{V}_{\text {in }}}{1-\mathrm{D}}\right]=\mathrm{V}_{\mathrm{c} 2}$

Substituting equation (33) in equation (32) then the voltage across the capacitor $\mathrm{C}_{1}$ is given by:

$\mathrm{V}_{\mathrm{c} 1}=-\left[\frac{\mathrm{V}_{\text {in }} \mathrm{D}}{1-\mathrm{D}}\right]$

\section{B. ANALYSIS OF SINGLE PHASE BIPOLAR SPWM INVERTER}

An Inverter is a circuit which converters DC Voltage or Current into AC voltage or current with particular magnitude and frequency. The output of $\mathrm{AC}$ voltage may be square wave. The e basic component of power, electronic switches like MOSFET, IGBT, or thirstier and gate drive circuit. The 1- $\Phi$ inverter is as shown in Fig 6

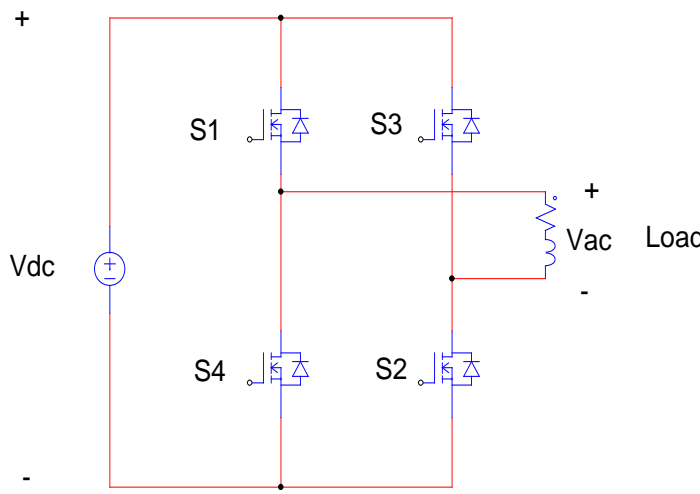

Fig 6 Circuit configuration of 1- $\Phi$ inverter
There are two types of gate driving system i.e. selfoscillating and external driven circuit. In the selfoscillating inverter the power electronic switch can be turned $\mathrm{ON}$ or $\mathrm{OFF}$ by the inherent magnetic characteristics, But the controlling is complex in this type of inverter. In the driven type inverter the power electronic switch can be turned ON or OFF by using external circuit. In order to improve the safety of solar system the galvanic isolation is necessary in the system i.e. high frequency or low frequency transformer at the side of inverter. But the galvanic isolation is bulky and increases the cost of system. Also it reduces the efficiency of the system. Then the transformer less PV system came into existence. In this method the PV panel is connected to grid which introduces ground leakage current. But as per the German standards (i.e. VDFO 126-1-1) the ground leakage current should not be greater than $0.3 \mathrm{~A}$ so that it avoids electrical hazard. The ground leakage current issue can be solved by implementing bipolar SPWM technique to 1- $\phi$ inverter.

The sinusoidal wave form is most common requirement for most of the loads. This can be achieved by using driven inverter technologies. To achieve the sinusoidal waveform, the sinusoidal pulse width modulation (SPWM) technique can be implemented. In order to control the switches of inverter using SPWM, it required reference signal (sinusoidal which is also called as modulating signal) Such that the frequency may be $50 \mathrm{~Hz}$ or $60 \mathrm{~Hz}$.

- Carrier signal (triangular signal) whose frequency is high i.e. Operates in switching frequency .In this method the bipolar SPWM technique implemented which is as shown in figure.

- When the reference (sinusoidal) signal is greater than carrier (triangular) signal the output voltage is +ve (positive).

$\left[\mathrm{S}_{1} \& \mathrm{~S}_{2}\right.$ are $\mathrm{ON}$ when $\left.\left(\mathrm{V}_{\text {sine }}<\mathrm{V}_{\text {tri }}\right)\right]$

- When the reference sinusoidal signal is lesser than the carrier triangular signal the output voltage is $-\mathrm{V}_{\mathrm{dc}}$ (negative)

$\left[\mathrm{S}_{3} \& \mathrm{~S}_{4}\right.$ are $\mathrm{ON}$ when $\left.\left(\mathrm{V}_{\text {sine }}<\mathrm{V}_{\text {tri }}\right)\right]$

The implementation of bipolar SPWM technique is as shown in Fig 7. The reference sine wave has a frequency $50 \mathrm{~Hz}$ with amplitude of 0.8 . The carrier triangular wave has a frequency of $3 \mathrm{kHz}$ with amplitude 1 peak-to-peak.

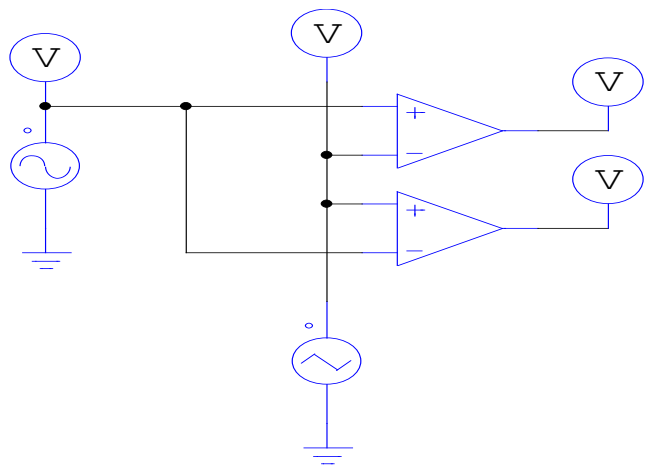

Fig 7 Implementation circuit of bipolar SPWM 


\section{International Journal of Innovative Research in Electrical, Electronics, Instrumentation and Control Engineering \\ ISO 3297:2007 Certified}

Vol. 5, Issue 1, January 2017

\section{IMPLEMENTATION OF MAXIMUM POWER POINT TRACKING ALGORITHM}

The concept of maximum power point tracking emerged due to the low power efficiency of solar panel which is in the order of $20 \%$ to $21 \%$. The solar panels are usually installed in such a way that the maximum intensity of sun rays fall on the panel. The panels are placed in non-shaded areas.

The power output of the solar panel varies as the temperature and the solar irradiance varies. The performance of the solar panel is determined by using $\mathrm{I}-\mathrm{V}$ characteristics of the solar panel. The I-V and P-V characteristics are non-linear in nature thus it is necessary to implement MPPT algorithm for the better performance of solar application. The I-V characteristics and P-V characteristics of the solar panel also impacted by the temperature and solar irradiance.

The maximum power is obtained by differentiating power with respect to voltage $(\mathrm{dP} / \mathrm{dV})$ and equating it to zero. The PV array voltage $\left(\mathrm{V}_{\mathrm{pv}}\right)$ is regulated in such a manner that it increases when $\mathrm{dP} / \mathrm{dV}$ slope is positive and it decreases when $\mathrm{dP} / \mathrm{dV}$ slope is negative.

From the definition, MPPT is an algorithm whuch is combined to DC-DC converter so that it allows photovoltaic array to generate maximum power continuously irresoective of metrological conditions (temperature and irradiance).

The MPPT algorithm consists of two major components. They are controller stage and power stage with two configurations.

- Controller using input parameters: In this method, the parameters of PV generation such as PV voltage and current are used by controller for tracking purpose. In this method the duty cycle $\alpha$ is dependent on PV panel when it achieves maximum power point.

- Controller using output parameters: In this method, the load voltage and current parameters are used by controller in order to track the maximum power point. Here the duty cycle $\alpha$ is controller based on load requirements by sensing voltage and current.

There are two methods of implementing MPPT technique.

- Perturb and observe method ( $\mathrm{P} \& \mathrm{O}$ method).

- Incremental conductance method.

\section{MPPT algorithm:}

Perturb and observe method is based on iterative technique to track maximum power continuously via voltage and current measurement from the PV panel. Perturb and Observe $(\mathrm{P} \& \mathrm{O})$ is the MPPT technique which is preferred for low power applications. It is also called as hill climbing technique. This technique is reliable and simple to implement. In this algorithm code, the voltage of the photovoltaic array module is deviated by a small increment $(\Delta \mathrm{V})$ which results in the change in power. If the change in power is more than zero, then it is inferred that the operating point is closer to MPPT.

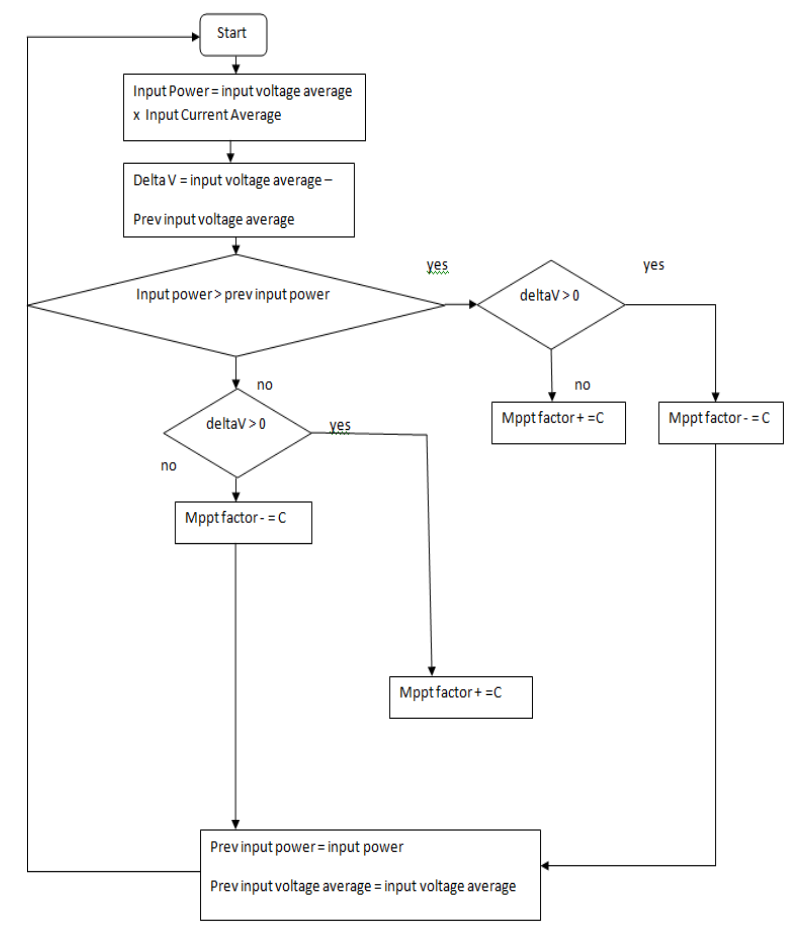

Fig 8 Flowchart of the Perturb and Observe MPPT technique

Therefore, the further deviations are obtained in the same direction such that the operating point gets closer to the MPP. If change in power is less than zero, then it is inferred that the operating point is away from the MPPT. Hence the next shift is carried out on the opposite direction. The flowchart of the Perturb and Observe algorithm is as shown in the Fig 8

\section{EXPERIMENT RESULTS}

The simulation work is carried out in PSIM. The main intention of this project is to reduce the ripple current and ground leakage current to nearly zero and the respective figures are shown in this chapter. Fig 9 shows the simulation model of boost converter. Fig 10 shows the simulation model modified boost converter. Fig 11 shows comparison of inductor currents between boost and modified boost converter with DC source as input. For the modified Boost converter there is no ripple current in inductor compared to conventional to boost converter. Fig 12 shows Input and Output voltage waveforms of Modified Boost converter. The simulation parameters are shown in Table 1.

Table 1: Simulation parameters of modified boost converter

\begin{tabular}{|l|l|l|}
\hline Sl. no & Parameter & Value \\
\hline 1 & Input voltage & $120 \mathrm{~V}$ \\
\hline 2 & Inductor $\mathrm{L}_{1}$ & $3 * 10^{-3} \mathrm{H}$ \\
\hline 3 & Inductor $\mathrm{L}_{2}$ & $3 * 10^{-3} \mathrm{H}$ \\
\hline 4 & Capacitor $\mathrm{C}_{1}$ & $10^{*} 10^{-6} \mathrm{~F}$ \\
\hline
\end{tabular}


IJIREEICE

International Journal of Innovative Research in Electrical, Electronics, Instrumentation and Control Engineering

ISO 3297:2007 Certified

Vol. 5, Issue 1, January 2017

\begin{tabular}{|l|l|l|}
\hline 5 & Capacitor $\mathrm{C}_{2}$ & $10^{*} 10^{-6} \mathrm{~F}$ \\
\hline 6 & Output Voltage of converter & $400 \mathrm{~V}$ \\
\hline
\end{tabular}

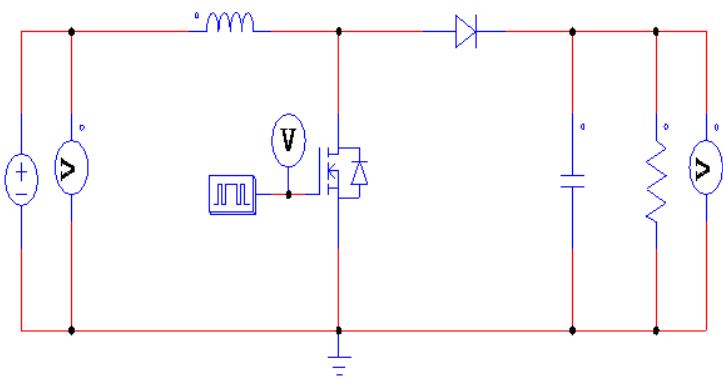

Fig 9 Simulation model of Boost converter

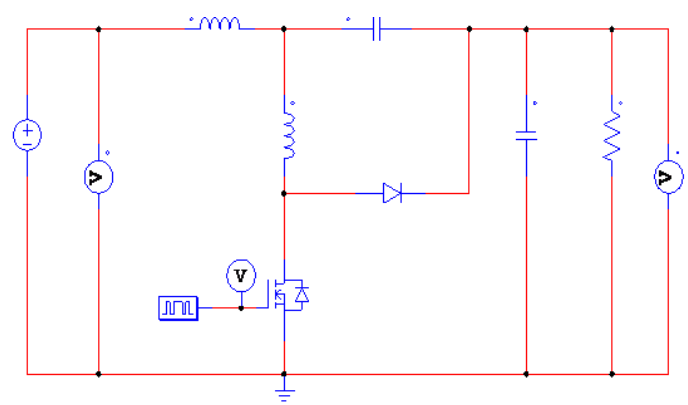

Fig 10 Simulation model of Modified Boost converter
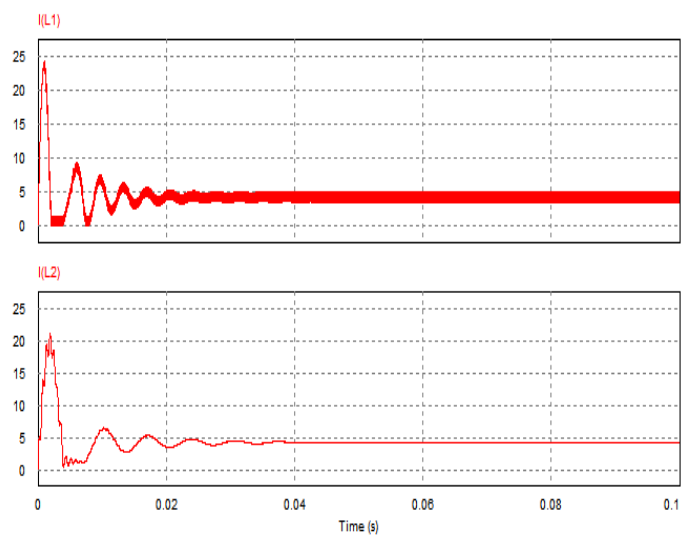

Fig 11 Inductor current waveforms of Boost and Modified Boost converter

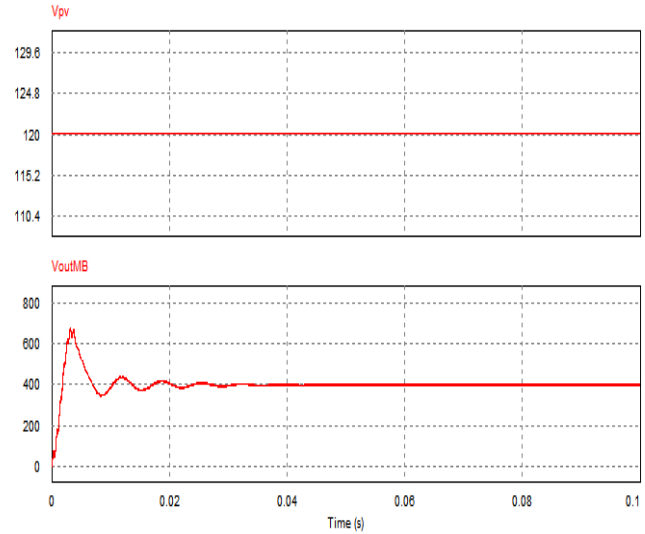

Fig 12 Input and Output voltage waveforms of Modified Boost converter
The I-V and P-V characteristics of PV panel for different radiations and the results are shown in Fig 13. The parameters of solar panel are given in table 2 .

Table 2 Parameters of solar panel

\begin{tabular}{|c|c|c|}
\hline Sl.No & Parameter & Value \\
\hline 1 & Number of cells in series & 36 \\
\hline 2 & Standard light intensity & $1000 \mathrm{~W} / \mathrm{m}^{2}$ \\
\hline 3 & Reference temperature & $25^{0} \mathrm{C}$ \\
\hline 4 & Series resistance $\left(\mathrm{R}_{\mathrm{s}}\right)$ & $0.00 \Omega^{\prime} \Omega$ \\
\hline 5 & Shunt resistance $\left(\mathrm{R}_{\mathrm{sh}}\right)$ & $1000 \Omega$ \\
\hline 6 & Short-circuit current & $3.8 \mathrm{~A}$ \\
\hline 7 & Saturation current & $2.16^{*} 10^{-8} \mathrm{~A}$ \\
\hline 8 & Band energy & $1.2 \mathrm{eV}$ \\
\hline 9 & Ideality factor & 2 \\
\hline 10 & Temperature coefficient & $0.0024 \mathrm{~A} / \mathrm{K}$ \\
\hline
\end{tabular}
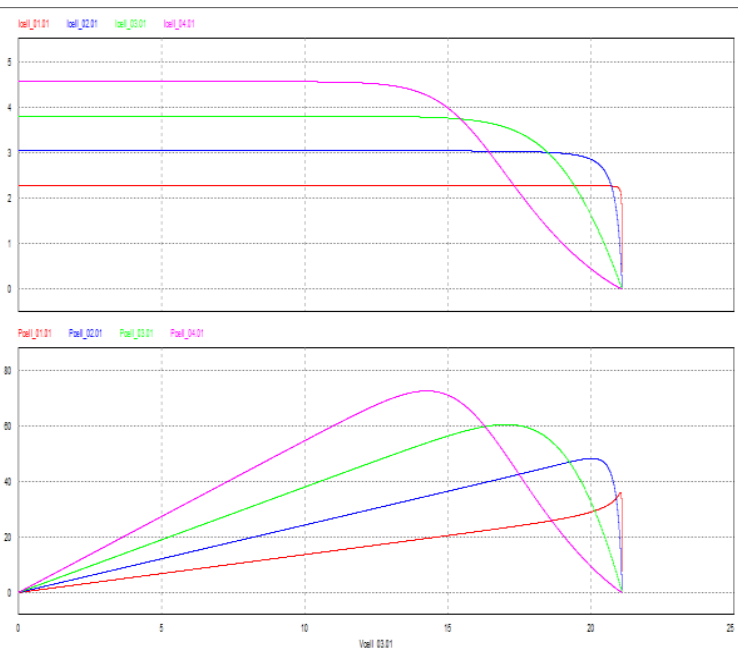

Fig 13 I-V and P-V characteristics

The simulation of modified boost converter with solar input is as shown in Fig 14. Figure 15 shows the waveform of PV array voltage and DC output voltage. The ground leakage current which is nearly zero is shown in Fig 16

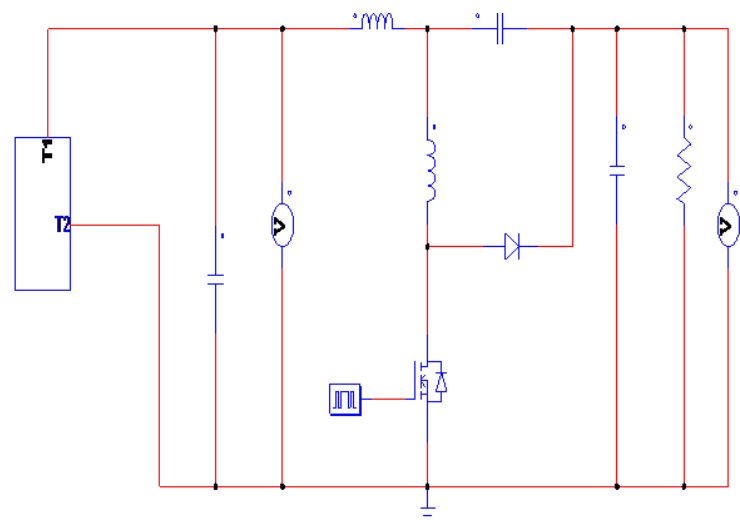

Fig 14 Simulation of Modified Boost converter with solar panel as input 
International Journal of Innovative Research in Electrical, Electronics, Instrumentation and Control Engineering

ISO 3297:2007 Certified

Vol. 5, Issue 1, January 2017
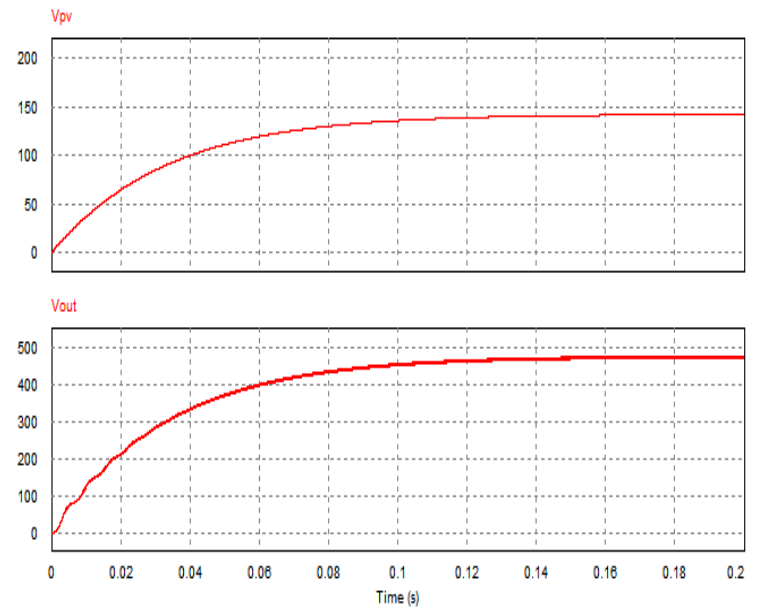

Fig 15 Waveforms of PV array voltage and DC output voltage

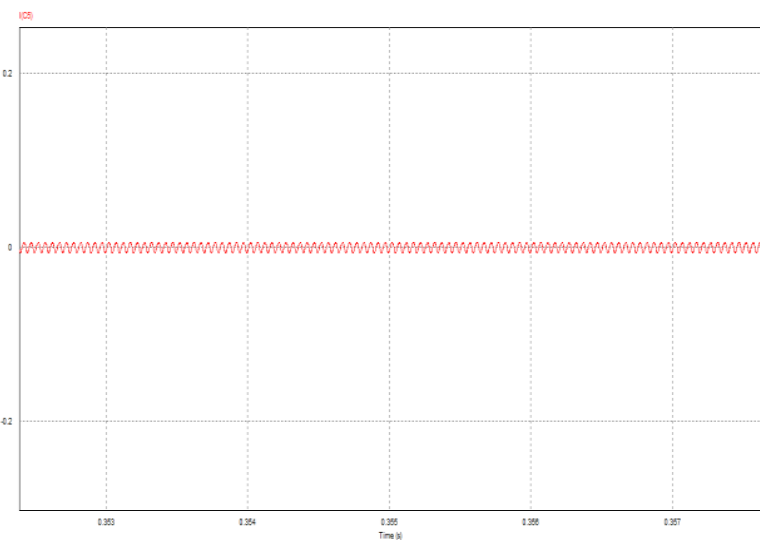

Fig 16 Ground leakage current

The simulation circuit of Maximum power point tracking (MPPT) technique is as shown in Fig 17. The results are shown in Fig 18. The MPPT technique used is perturb and observe $(\mathrm{P} \& \mathrm{O})$.

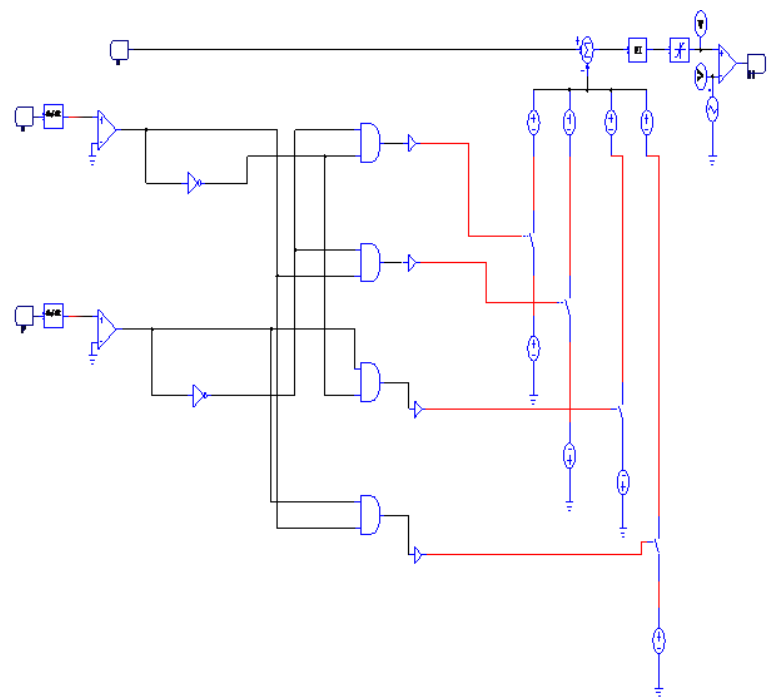

Fig 17 Perturb and Observe MPPT circuit

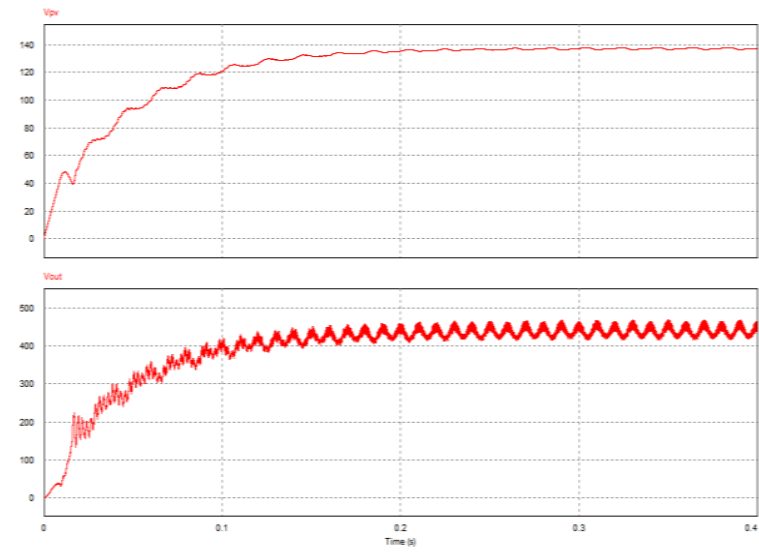

Fig 18 Waveforms of PV array voltage and DC output voltage

In order to control the inverter the bipolar sinusoidal pulse-width modulation (SPWM) technique is implemented. The simulation circuit is as shown in Fig 19. The results are shown in Fig 20

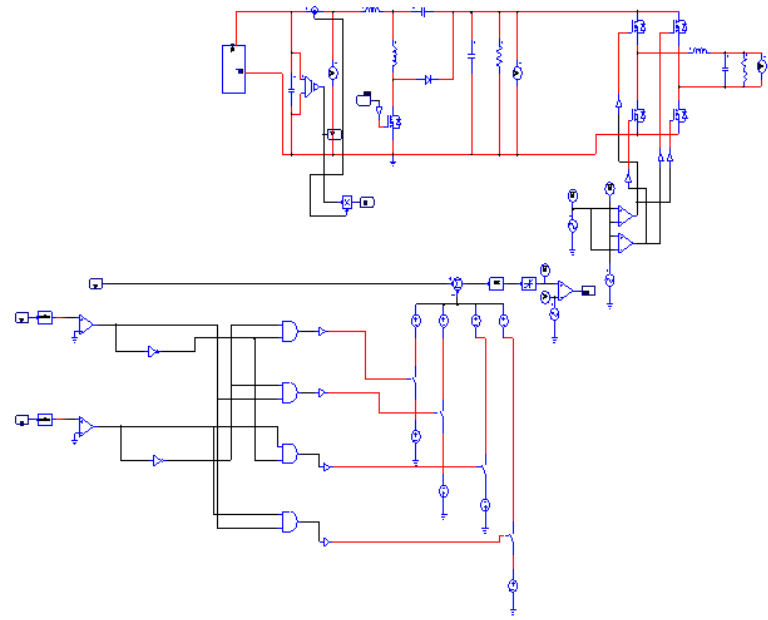

Fig 19 Simulation model of circuit with MPPT and Bipolar SPWM

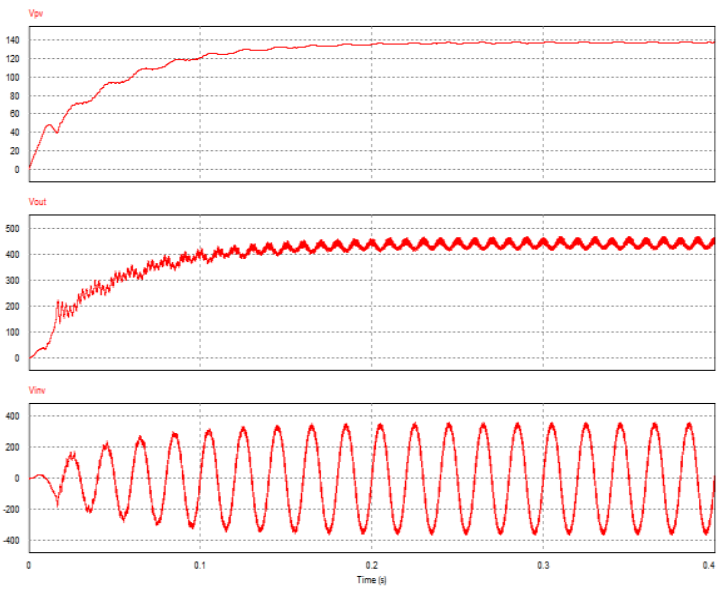

Fig 20 Waveforms of PV array voltage, DC link voltage, and Load voltage. 


\section{CONCLUSION}

- In this project, the transformer less grid-connected system using PV panel is proposed.

- The proposed converter (i.e. modified boost converter) is compared with conventional boost converter and it is found that input current ripple and efficiency are improved.

- In the traditional boost converter the input ripple current is high because of inductance in series with source and it is not in case of modified boost converter. Hence, for sources like PV panel, modified boost converter is more advantageous when compared to traditional boost converter.

- The improvements in the conventional boost converter led to the elimination of the high frequency transformer at the DC side which may cause ground leakage current at the inverter side. This issue is resolved by implementing bipolar SPWM technique for controlling the inverter switches. In the simulator it is observed that after implementing bipolar SPWM the ground leakage current is maintained less than $300 \mathrm{~mA}$ which satisfies the norms of German standards VDE0126-1-1.

\section{A. SCOPE FOR FUTURE WORK}

In this methodology, the modified boost converter is implemented for PV applications and 1- $\Phi$ inverter with bipolar SPWM technique is implemented. The P\&O MPPT technique is implemented to maximize the efficiency of solar panel. In MPPT technique the Proportional-Integral (PI) controller is used. Fuzzy logic controller can be implemented instead of this scheme. Also, the work may be extended to implement 3- $\Phi$ inverters with space vector PWM (SVPWM) technique which have the following advantages:

- It is generally suitable for digital implementation.

- It provides the effective utilization of the DC link voltages comparatively.

- The harmonic content is relatively low.

- The switching frequency of the switches in the inverter is half of the carrier frequency. But in the SPWM technique the switching frequency is equal to switches of the inverter. Hence it can be concluded that switching losses are low in this technique when compared to other techniques.

\section{ACKNOWLEDGEMENT}

A dissertation work of this nature requires co-ordination and support from many for its successful completion and I am fortunate enough in this direction. It gives me great pleasure to acknowledge and express my deep sense of gratitude to those who have helped me throughout this work.

I am highly indebted to my internal guide Dr. N. S. Jyothi, Associate Professor, Department of Electrical and Electronics Engineering, Malnad College of Engineering,
Hassan, for his excellent guidance, encouragement and support throughout the course. I consider it to be an honour for working under him.

I wish to express deep sense of gratitude to my parents and family for their constant encouragement and support. Finally, I thank all my well wishers, friends and those who directly or indirectly helped me during the course of completion of the dissertation work.

\section{REFERENCES}

[1]. S. Heier, Grid Integration of Wind Energy Conversion Systems. Hoboken, NJ: Wiley, 1998.

[2]. G. L. Johnson, Wind Energy Systems. Englewood Cliffs, NJ: Prentice- Hall, 1985.

[3]. S. Muller, M. Deicke, and R. W. De Doncker, "Doubly fed induction generator systems for wind turbines," IEEE Ind. Appl. Mag., vol. 8, no. 3, pp. 26-33, May/Jun. 2002.

[4]. F. M. Hughes, O. Anaya-Lara, N. Jenkins, and G. Strbac, "Control of DFIG-based wind generation for power network support," IEEE Trans. Power Syst., vol. 20, no. 4, pp. 1958-1966, Nov. 2005.

[5]. M. Orabi, F. El-Sousy, H. Godah, and M. Z. Youssef, "Highperformance induction generator-wind turbine connected to utility grid," in Proc $26^{\text {th }}$ Annu. INTELEC, Sep. 19-23, 2004, pp. 697704.

[6]. J. M. Peter, "Main future trends for power semiconductors from the state of the art to future trends," presented at the PCIM, Nürnberg, Germany, Jun. 1999, Paper R2 667-671.

[7]. H. Grüning et al., "High power hard-driven GTO module for 4.5 kV/3 kA snubberless operations," in Proc. PCI Eur., 1996, pp. 169183.

[8]. E.ON Netz Grid Code. Bayreuth, Germany: E.ON Netz GmbH, Aug. 1, 2003.

[9]. D. Foussekis, F. Kokkalidis, S. Tentzevakis, and D. Agoris, "Power quality measurement on different type of wind turbines operating in the same wind farm," presented at the EWEC (Session BT2.1 Grid Integration), Madrid, Spain, Jun. 16-19, 2003.

[10]. M. Victor, F. Greizer, S. Bremicker, and U. Hübler, "Method of converting a direct current voltage from a source of direct current voltage, more specifically from a photovoltaic source of direct current voltage, into a alternating current voltage," U.S. Patent 7 411 802, Aug. 12, 2008.

[11]. R. Gonzalez, E. Gubia, J. Lopez, and L. Marroyo, "Transformerless single-phase multilevel-based photovoltaic inverter," IEEE Trans. Ind. Electron., vol. 55, no. 7, pp. 2694-2702, Jul. 2008.

[12]. E. Gubia, P. Sanchis, and A. Ursua, "Ground currents in singlephase transformerless photovoltaic systems," Prog. Photovolt., vol. 15, no. 7, pp. 629-650, May 2007.

[13]. R. Ruther, A. J. G. daSilva, A. A. Montenegro, and I. T. Salamoni, "Assessment of thin-film technologies most suited for BIPV applications in Brazil: The PETROBRAS $44 \mathrm{kWp}$ project," in Proc. 3rd World Conf. Photovoltaic Energy Convers., Osaka, Japan, 2003, pp. 2294-2297.

[14]. X. L. Li, "Application of CIS thin film solar cells in the BIPV system with large commercial project," New Energy Environ., vol. 37, pp. 46-48, 2008.

[15]. H. du Toit Mouton, "Natural balancing of three-level neutralpointclamped PWM inverters," IEEE Trans. Ind. Electron., vol. 49, no. 5, pp. 1017-1025, Oct. 2002.

[16]. R. Stala, S. Pirog, M. Baszynski, A. Mondzik, A. Penczek, J. Czekonski, and S. Gasiorek, "Results of investigation of multicell converters with balancing circuit-Part I," IEEE Trans. Ind. Electron., vol. 56, no. 7, pp. 2610-2619, Jul. 2009

[17]. P. N. Tekwani, R. S. Kanchan, and K. Gopakumar, "A dual fivelevel inverter-fed induction motor drive with common-mode voltage elimination and DC-link capacitor voltage balancing using only the switchingstate redundancy-Part II," IEEE Trans. Ind. Electron., vol. 54, no. 5, pp. 2609-2617, Oct. 2007. 